IZA DP No. 4279

Religion, Human Capital Investments and the Family in the United States

Evelyn L. Lehrer

July 2009 


\title{
Religion, Human Capital Investments and the Family in the United States
}

\author{
Evelyn L. Lehrer \\ University of Illinois at Chicago \\ and IZA
}
Discussion Paper No. 4279
July 2009

IZA

P.O. Box 7240

53072 Bonn

Germany

Phone: +49-228-3894-0
Fax: +49-228-3894-180
E-mail: iza@iza.org

Any opinions expressed here are those of the author(s) and not those of IZA. Research published in this series may include views on policy, but the institute itself takes no institutional policy positions.

The Institute for the Study of Labor (IZA) in Bonn is a local and virtual international research center and a place of communication between science, politics and business. IZA is an independent nonprofit organization supported by Deutsche Post Foundation. The center is associated with the University of Bonn and offers a stimulating research environment through its international network, workshops and conferences, data service, project support, research visits and doctoral program. IZA engages in (i) original and internationally competitive research in all fields of labor economics, (ii) development of policy concepts, and (iii) dissemination of research results and concepts to the interested public.

IZA Discussion Papers often represent preliminary work and are circulated to encourage discussion. Citation of such a paper should account for its provisional character. A revised version may be available directly from the author. 


\section{ABSTRACT}

\section{Religion, Human Capital Investments and the Family in the United States}

This paper critically reviews what is known, based on analyses of micro-level U.S. data, about the role of religion in various interrelated decisions that people make over the life cycle, including investments in secular human capital, cohabitation, marriage, divorce, family size and employment. It also identifies gaps in our knowledge, and suggests agenda items for future research in the field. These include use of statistical models that allow for nonlinearities in the effects associated with religious participation; consideration of contextual effects; and analyses that address anomalies found in earlier work regarding patterns of nonmarital sex and divorce among conservative Protestants. Further work is also needed to increase our understanding of the role that religious factors are playing as various dimensions of the second demographic transition, along with elements of "American exceptionalism," continue to unfold in the U.S.

JEL Classification: J1, J2

Keywords: religion, religiosity

Corresponding author:

Evelyn L. Lehrer

Economics Department (M/C 144)

University of Illinois at Chicago

601 South Morgan Chicago, IL 60607

USA

E-mail: elehrer@uic.edu

\footnotetext{
* Forthcoming in The Oxford Handbook of the Economics of Religion, edited by Rachel M. McCleary. For some of the ideas developed in this paper, I benefited from discussions with Lawrence Officer and with participants at seminars I presented at the Economics Department, University of Illinois at Chicago (November 25, 2008) and the Demography Workshop, NORC and University of Chicago (December 4, 2008).
} 
Religion, Human Capital Investments and the Family in the United States

In this chapter I critically review what is known about the role of religion in human capital investments and the family in the United States, based on analyses of micro-level data. I also identify gaps in our knowledge, and suggest an agenda for future research in the field.

The economic perspective views an individual's religious affiliation as affecting economic and demographic behavior because the norms and teachings of various faiths influence the perceived benefits and costs of numerous decisions that people make over the life cycle, including choices regarding the pursuit of investments in secular human capital, cohabitation, marriage, divorce, family size, and employment. These decisions are closely interrelated, so when religious teachings directly influence any one of them, all others are indirectly affected (Lehrer 2004a).

Consistent with existing structures of perceived benefits and costs, several religious groups in the U.S. exhibit patterns of economic and demographic behavior that differ significantly from those of mainline Protestants. Conservative Protestants stand out for their tendency to avoid cohabitation and enter marriage and childbearing at a young age (Lehrer 2004b; Glass and Jacobs 2005; Uecker and Stokes 2008; Fitzgerald and Glass 2008); their low level of education (Darnell and Sherkat 1997; Sherkat and Darnell 1999; Lehrer 1999; 2004c; Glass and Jacobs 2005); greater asymmetry in the intra-household division of labor (Ellison and Bartkowski 2002); low levels of employment when young children are present in the household (Lehrer 1995; Sherkat 2000; Glass and Nath 2006); relatively high fertility (Lehrer 1996; Hout, Greeley and Wilde 2001); and low levels of female wages (Lehrer 2005) and of family wealth (Keister 2003, 2005, 2009a, 2009b). At the same time, non-Orthodox Jews tend to display opposite patterns, including delayed entry to marriage (Lehrer 2004b), low fertility (Mosher and Hendershot 1984); high educational attainment (Chiswick 1988; Lehrer 1999); high level of female employment except when young children are present in the household (Chiswick 1986; 
Hartman and Hartman 1996); high wages (Chiswick 1988; Lehrer 2005) and high levels of wealth (Keister 2003, 2005, 2009a). Research on Mormons shows a pattern of unusually high fertility (Heaton 1986; Lehrer 1996); high marital stability among homogamous unions (Lehrer and Chiswick 1993); a low level of female employment (Heaton and Cornwall 1998) and low female wages (Lehrer 2005). As to Catholics, the major drop in religious commitment that followed Vatican II (Finke and Stark 2006) led to a convergence to the mainline Protestant pattern in virtually all areas of economic and demographic behavior (Westoff and Jones 1979; Lehrer 1995, 1999).

The "no religion" group has been found to be associated with lower levels of educational attainment (Keysar and Kosmin 1995; Glass and Jacobs 2005; Lehrer 2005) and higher levels of marital instability (Lehrer and Chiswick 1993). But this category is heterogeneous-- including atheists, agnostics, and people who report no affiliation for other reasons, such as being raised in an inter-faith home-- and findings for other economic and demographic outcomes are mixed. A growing number of Americans are self identifying as unaffiliated (Kosmin and Keysar 2006), and disaggregating the various components of this category is becoming increasingly important.

For behaviors that pertain to married-couple households, religious affiliation also matters because it is a complementary trait within marriage, for which positive assortative mating is optimal (Becker 1973). There is less efficiency and more conflict in households where the partners do not share the same affiliation, and consistent with this, religious heterogamy is associated with a higher rate of marital instability, especially if one of the partners is affiliated with a faith near the exclusivist end of the ecumenical-exclusivist continuum (Becker et al. 1977; Lehrer and Chiswick 1993; see also Vaaler et al. 2009). In addition, consistent with their higher expected rate of divorce, there is some evidence that inter-faith couples restrict their fertility (Becker et al. 1977; Lehrer 1996) and have elevated levels of female employment (Lehrer 1995). 
Beyond affiliation, another important dimension of religion is participation in religious services within a congregation; through such participation people increase their stock of religious human capital (lannacconne 1990). Some participation has been associated in the literature with a wide range of beneficial effects, including less substance use and delinquency among youth (Donahue and Benson 1995); improved parent-child relations (Pearce and Axinn 1998); and better educational outcomes (Regnerus 2000; Muller and Ellison 2001; Lehrer 2005). In addition, marital stability has been found to be higher among homogamous couples in which both spouses attend religious services regularly (Vaaler et al. 2009). These positive outcomes reflect in part a social capital effect (religion integrates people into supportive networks); a regulative effect (most religious traditions encourage constructive, healthy behaviors); and the psychological benefits of involvement in religious activities (Waite and Lehrer 2003; see also Smith 2003 and Vaaler et al. 2009).

A higher level of religious participation can also affect economic and demographic behavior by accentuating the effects of affiliation: religious teachings should be more salient in decision making among individuals who have a high level of involvement in their faith. Since religions differ in their teachings, this second channel of influence implies that we should not expect universal relationships, with a higher level of religious participation having consistent effects across affiliations. For example, elements of conservative Protestantism discourage investments in secular schooling, and this tendency should be more visible among those with a stronger commitment to their religion; at the highest levels of religious participation this influence could cancel or dominate the generally positive effects of some religious involvement noted above. ${ }^{1}$

Additional discussion of these effects of religious affiliation and participation on economic and demographic behavior-- with the empirical analyses based mostly on data on non-Hispanic whites in the United States-- is available elsewhere (Lehrer 2009). The remainder of this chapter focuses on recent developments and emerging new directions in the field. 


\section{Statistical Methods}

Some studies in the literature-- including all of my own work-- have examined how the religious affiliation in which an individual was raised and the level of religious participation in early adolescence are associated with subsequent economic and demographic behaviors and outcomes. This focus on childhood measures of affiliation and participation, coupled with rich background controls, helps alleviate problems of endogeneity. However, many studies--e.g., most of the existing work on the religion-fertility connection-- conduct single-equation analyses using contemporaneous measures of religion. The results from this body of research are difficult to interpret, since religious affiliation in adulthood is a choice variable, especially in the vibrant U.S. religious marketplace where it is not unusual for people to switch affiliations as they search for a better match in the spiritual, socioeconomic, and/ or demographic arenas (Sander 1992; Sherkat and Wilson 1995; Roof 1999). Religious switching is especially common in connection with migration, marriage, and divorce (Stark and Finke 2000). The extent of current religious participation is also endogenous to contemporaneous economic and demographic behaviors. For example, entry into cohabitation has been linked to diminished religious participation, in part because cohabitors who attend religious services may experience cognitive dissonance or encounter opposition in their congregations (Uecker et al. 2007); and the presence of school-aged children has been linked to increased participation, as parents seek to transmit their religious beliefs to the next generation (Stolzenberg et al. 1995). Furthermore, a host of unobserved variables that affect choices regarding religion can simultaneously influence economic, demographic and health behaviors.

Increasingly, the implications of the bidirectional nature of these relationships and problems of selectivity are being recognized in the literature. The nature of the resulting biases, however, is often misunderstood. For example, it has been argued that estimates of the beneficial effects of some religious participation on educational outcomes are upwardly biased, because of the correlation 
between churchgoing and constructive, unobserved behaviors (Freeman 1986). However, to the extent that involvement in religious activities is recognized as a valuable coping mechanism and is disproportionately embraced in families that are vulnerable- e.g., due to unobserved health problems or economic hardship-- the estimates would understate the true beneficial impact of religious participation. Similarly, contrary to conventional wisdom, it is unclear a priori whether current estimates overstate or understate the generally beneficial effects of religious participation on health outcomes.

A new generation of studies has proposed novel approaches to estimating the causal effects of religious participation. Gruber (2005) finds that individuals who live in areas with a high density of their religion, as proxied by the ancestral mix of area residents, have higher levels of religious participation, leading to more favorable outcomes in several dimensions, including education, income, and marital status. Gruber and Hungerman (2008) show how the repeal of "blue laws" in several states led to increased attendance to religious services, and in turn, to an increase in drinking and drug use among individuals who initially attended religious services and were affected by such laws. Along similar lines, ongoing research relies on changes in these laws to shed new light on the religious participation - happiness connection (Cohen-Zada and Sander 2009). Also noteworthy is work in progress that uses longitudinal data on siblings who differ in their levels of religious participation during adolescence to estimate the causal impact of such participation on subsequent educational outcomes (Hakim Orman, North and Gwin 2009).

\section{Specification of Religious Participation Variable}

Studies that link religious participation to beneficial outcomes, including my own earlier work, have generally been based on models that specify the participation variable as continuous or as a simple dummy for high versus low participation. This is a serious limitation, as suggested by recent work that has moved to specifications that permit identification of potential non-linearities. Based on a 
sample of Jews, Chiswick and Huang (2008) find that individuals who attend religious services weekly have higher earnings than their counterparts who attend less frequently, but those who attend more than weekly have lower earnings than those who attend weekly. The authors suggest that these results may in part reflect a crowding-out effect, as more time devoted to religious participation begins to imply less time available for secular endeavors.

Using data from Chile, another study finds non-linearities in the religious participation intimate partner violence relationship (Lehrer et al. 2009): some religious involvement is associated with a protective effect for victimization-- reflecting the generally healthier lifestyles associated with such involvement--but a high level is not. This result is consistent with ethnographic research in the U.S. which shows that religion is generally a constructive force that decreases the risk of both perpetration of intimate partner violence and victimization. But at the same time, damaging effects can be seen at the very high levels of religious participation and commitment often associated with conservative theological beliefs, e.g., encouraging traditional gender roles, condemning divorce. In all religious traditions, including Christianity, Judaism, and Islam, such beliefs can be taken to an unhealthy extreme, and misinterpreted to condone men's violent behaviors and to encourage women to remain in abusive relationships (Nason-Clark 2004; Levitt and Ware 2006).

Similar non-linearities are likely to be present in relationships of religious participation with other outcomes, such as education and mental health, and if so the findings reviewed earlier, linking such participation to beneficial influences, may well have been driven by cases of moderate religious participation. Thus the question that has guided the research agenda to date-- "Is religion good for you?" (Gruber 2005) -- would best be re-stated to recognize the nuanced nature of religious participation effects, which can range from beneficial to adverse, and future studies should use specifications that allow for non-linear effects. In addition, more attention needs to be paid in this strand of the literature to the distinction between normative and positive statements. In many cases, 
what is or is not beneficial is unambiguous: incidents of intimate partner violence or substance use averted are clearly desirable, as is graduating from high school. There is less clarity in other domains that are affected by religion. For example, a tradeoff is involved when the practice of a faith leads adherents to allocate more time to family and less to labor market activities, resulting in lower levels of wealth accumulation.

\section{Specification of Religious Affiliation Variables, and Other Dimensions of Religion}

Progress has also been made in the literature in the specification of the religious affiliation variables, especially with regard to an improved classification scheme for Protestant denominations (Steensland et al. 2000), as well as better understanding of heterogeneity within conservative Protestantism and the implications of different ways to identify conservative Protestants (Woodberry and Smith 1998; Hackett and Lindsay 2008). In addition, several studies have demonstrated the usefulness of considering a richer array of religious variables beyond affiliation and participation, including theological beliefs (e.g., in Bible inerrancy, miracles) and the salience of religion and private religiosity (Idler et al. 2003; Glass and Nath 2006; Vaaler et al. 2009; Sherkat 2009). A common problem in the literature is that measures of both religious affiliation and participation are entered into regressions, without attention paid to the high correlation between these variables. Even more caution in this regard will be needed as additional measures of religion-- all highly correlated-- begin to be incorporated to the analyses.

\section{Contextual Effects}

At a time when studies based on national U.S. data were reporting an end to Catholic fertility, Williams and Zimmer (1990) found a pattern of continued high Catholic fertility in Rhode Island: religion mattered more in this state because of the majority status of Catholics. Along similar lines, Stark 
(1996) finds that the relationship between teen's religious participation and decreased delinquency is only visible in states where levels of religious participation are relatively high and religion is important in people's everyday interactions. In light of major variations in the religious landscape across regions of the U.S. coupled with compelling theoretical reasons to expect contextual effects, wherever possible future work should use models that allow the influence of religion at the individual level to vary with the religious environment. International variations in the religious map are even more pronounced, and so we should not be surprised to find that relationships that have been established in the U.S. do not transfer to other countries. For example, while a large body of U.S. research shows that conservative Protestantism is associated with low socioeconomic status, work in progress finds that the expansion of Pentecostalism in Brazil has been associated with an increase in male income (Potter et al. 2009).

\section{Two Anomalies: Patterns of Non-Marital Sex and Divorce and Among Conservative Protestants}

The distinctive economic and demographic behaviors of various religious groups in the U.S. are generally in line with religious teachings and the structure of costs and benefits of various decisions that they imply, but two anomalies have been noted recently with regard to conservative Protestants. Regnerus (2007) finds that other factors held constant, conservative Protestant adolescents display above average sexual activity patterns, often without use of contraception. He explains this puzzle as resulting from a clash of cultures: conservative Protestant youths "are urged to drink deeply from the waters of American individualism and its self-focused pleasure ethic, yet they are asked to value time-honored religious traditions like family and chastity.... a combination that breeds instability and the persistent suffering of consequences like elevated teen pregnancy rates" (p. 206). An alternative interpretation is that these patterns are another instance of religiosity taken to an extreme, with adverse consequences. ${ }^{2}$ Other work finds that although adolescents who take a pledge of abstinence enter sexual activity later, most eventually do engage in non-marital sex and when they 
do, they have a lower rate of condom use at first sexual intercourse (Bruckner and Bearman 2005). The effects of conservative Protestant affiliation and high salience of religion on a key related outcome-- out-of-wedlock childbearing -- depend also on how religion influences decisions on how to resolve unwanted teen pregnancies. Each of these under-researched linkages deserves more attention in future work.

With regard to marital instability, it is not surprising that the "Bible belt" states have high divorce rates (Lesthaege and Neidert 2006), because conservative Protestants have relatively low levels of schooling and early entry into marriage, both of which are associated with unstable unions (Lehrer 2003). What is unexpected, given the strong pro-family messages of conservative Protestantism, is that even when these and other factors are held constant, this group does not have unions that are particularly stable (Lehrer and Chiswick 1993). Cherlin (2009) suggests an explanation in terms of the adaptation of conservative Protestant religious congregations to the cultural model of individualism in American society. As he observes, the relatively high level of marital instability among conservative Protestants is "not because religion tells them that divorce is good but because it tells them that self-development is good and that if they divorce, they will be forgiven and cared for" ( $p$. 134).

More generally, Cherlin (2009) comments on the pattern of numerous transitions into and out of cohabiting and marital unions in the U.S., especially in middle and lower SES groups. Little is known about how religious factors are influencing the formation and dissolution of all these unions, including "fragile families" where unmarried parents raise their children together, but research in this direction has begun (Wilcox and Wolfinger 2006; Wolfinger and Wilcox 2008). 
The Role of Religion in the Second Demographic Transition

The high level of fertility in the U.S., compared to that in other industrialized countries, has been attributed in part to institutional adaptability: flexible labor markets that facilitate women's ability to combine motherhood and employment, and a vibrant religious marketplace which encourages the high levels of religious participation that are conducive to high fertility (Adsera 2004; Frejka and Westoff 2008; Preston and Hartnett 2009). Yet ethnic factors also play a major role in maintaining high fertility, and, as Lesthaeghe and Neidert (2006) observe (p. 694), "the United States is a textbook example of the second demographic transition where immigration and higher immigrant fertility compensate for subreplacement fertility of much of the native population."

Regarding other dimensions of the second demographic transition in the U.S., the divergent trajectories of higher and lower SES groups have been a source of concern. The former is increasingly witnessing patterns of delayed marriage and childbearing, high levels of female employment, fathers who are involved with child care, and high levels of marital stability. In contrast, the salient patterns in the latter are a retreat from marriage, increased out-of-wedlock childbearing, and highly unstable unions-- all of which are associated with decreased resources for children (McLanahan 2004). Behind these divergent trends are major cultural and socio-economic transformations, including changes in the bargaining power of women and men brought about by the contraceptive revolution, and forces including globalization and technological change that have increased income inequality (Akerlof et al. 1996; McLanahan 2004; Lemieux 2008).

As is clear from the discussion in this chapter, religion influences all of the economic and demographic behaviors outlined above. The lower SES group disproportionately includes white individuals affiliated with conservative Protestant denominations, and African-Americans and Hispanics of all religious affiliations. The small body of existing research on racial/ ethnic minorities shows that both the determinants of participation in religious activities and the effects of religion on economic and 
demographic/ health behaviors follow patterns that often differ in major ways from those that have been established for non-Hispanic whites (Ellison and Sherkat 1995; Glass and Nath 2006; Ellison et al. 2007; Cherlin 2009). The common practice in the field of analyzing pooled data with simple controls for race/ ethnicity should thus be avoided in the future. Further analyses of micro-level data focusing on these under-studied groups of the population will be critical in helping us understand the role that religious factors are playing as various dimensions of the second demographic transition, along with elements of "American exceptionalism" (Lesthaege and Neidert 2006), continue to unfold in the U.S.

\section{ENDNOTES}

1 These relationships have not yet been examined empirically. As discussed later in the text, earlier research has generally not allowed for non-linearities in the effects of religious participation (Lehrer 2005).

2 At the macro level these relationships are even clearer. Conservative religious values taken to an extreme in the U.S. have led to public health expenditures on ineffective abstinence only programs in high schools (Fortenberry 2005; Trenhom et al. 2007). 


\section{REFERENCES}

Adsera, A. (2004). "Changing Fertility Rates in Developed Countries: The Impact of Labor Market Institutions." Journal of Population Economics 17: 1-27.

Akerlof, G.A., Yellen, J.L. and Katz, M.I. (1996) "An Analysis of Out-of-Wedlock Childbearing in the United States." Quarterly Journal of Economics 111:277-317.

Becker, G.S. (1973) "A Theory of Marriage." Pp. 299-344 in T. W. Schultz. (ed.) Economics of the Family, Marriage, Children, and Human Capital, Chicago: University of Chicago Press.

Becker, G. S., Landes, E. M. and Michael, R.T. (1977) "An Economic Analysis of Marital Instability." Journal of Political Economy 85(6): 1141-1187.

Bruckner, H. and Bearman, P. (2005) "After the Promise: The STD Consequences of Adolescent Virginity Pledges." Journal of Adolescent Health 36:271-278.

Cherlin, A.J. (2009) The Marriage-Go-Round: The State of Marriage and the Family in America Today. New York: Alfred A. Knopf.

Chiswick, B. (1986) "Labor Supply and Investments in Child Quality: A Study of Jewish and nonJewish Women." Review of Economics and Statistics 68(4): 700-703.

- . - - (1988) "Differences in Education and Earnings Across Racial and Ethnic Groups: Tastes, Discrimination, and Investments in Child Quality." Quarterly Journal of Economics 103(3):571597.

and Huang, J. (2008). "The Earnings of American Jewish Men: Human Capital, Denomination, and Religiosity." Journal for the Scientific Study of Religion 47(4): 694-709.

Cohen-Zada, D. and Sander, W. (2009) "Religious Participation Versus Shopping: What Makes People Happier?" Unpublished manuscript.

Darnell, A., and Sherkat, D. E. (1997) "The Impact of Protestant Fundamentalism on Educational Attainment." American Sociological Review 62:306-315. 
Donahue, M. J. and Benson, P. L. (1995) "Religion and the Well-Being of Adolescents." Journal of Social Issues 51(2):145-160.

Ellison, C. G. and Bartkowski, P. J. (2002) "Conservative Protestantism and the Division of Household Labor Among Married Couples." Journal of Family Issues 23(8): 950-985.

Ellison, C. G. and Sherkat, D.E. (1995) "The 'Semi-involuntary Institution' Revisited: Regional Variations in Church Participation among Black Americans." Social Forces 73(4): 1415-1437.

Ellison, C. G., Trinitapoli, J.A., Anderson, K. and Johnson, B.R. (2007) "Race/Ethnicity, Religious Involvement, and Domestic Violence." Violence Against Women 13(11): 1094-1112.

Finke, R. and Stark, R. (2006) The Churching of America 1776-2005: Winners and Losers in Our Religious Economy. New Brunswick: Rutgers University Press.

Fitzgerald, S.T. and Glass, J. (2008) "Can Early Family Formation Explain the Lower Educational Attainment of U.S. Conservative Protestants?" Sociological Spectrum 28: 556-577.

Forteberry, J.D. (2005) "The Limits of Abstinence-Only in Preventing Sexually Transmitted Infections." Journal of Adolescent Health 36:269-270.

Freeman, R. B. (1986) "Who Escapes? The Relationship of Churchgoing and Other Background Factors to the Socioeconomic Performance of Black Male Youths from Inner-City Tracts." Pp. 353-376 in R. B. Freeman and H. J. Holzer (eds.) The Black Youth Employment Crisis, Chicago: University of Chicago Press.

Frejka, T. and Westoff, C.F. (2008) "Religion, Religiousness and Fertility in the US and in Europe." European Journal of Population 24(1):5-31.

Glass, J and Jacobs, J. (2005) "Childhood Religious Conservatism and Adult Attainment among Black and White Women." Social Forces 84(1): 555-579. 
Glass, J. and Nath, L.E. (2006) "Religious Conservatism and Women's Market Behavior Following Marriage and Childbirth." Journal of Marriage and the Family 68 (August): 611-629. Gruber, J. (2005) "Religious Market Structure, Religious Participation, and Outcomes: Is Religion Good for You?" Advances in Economic Analysis and Policy 5(1): article 5. http://www.bepress.com/bejeap/advances/vol5/iss1/art5

- - - - and Hungerman, D.M. (2008) "The Church Versus the Mall: What Happens when Religion Faces Increased Secular Competition?" The Quarterly Journal of Economics, May: 831-862.

Hackett, C. and Lindsay, D.M. (2008) "Measuring Evangelicalism: Consequences of Different Operationalization Strategies." Journal for the Scientific Study of Religion 47(3):499-514.

Hakin Orman, W., North, C. and Gwin, C. (2009) "Mom and Dad Took Me to Church." Presented at the annual meetings of the Association for the Study of Religion, Economics, and Culture, Detroit, Michigan.

Hartman, M. and Hartman, H. (1996) Gender Equality and American Jews. Albany, NY: State University of New York Press.

Heaton, T. B. (1986) "How Does Religion Influence Fertility? The Case of Mormons." Journal for the Scientific Study of Religion 25(2): 248-258.

- - - - and Cornwall (1989) "Religious Group Variation in the Socio-Economic Status and Family Behavior of Women." Journal for the Scientific Study of Religion 28(3): 283-299.

Hout, M., Greeley, A., and Wilde, M.J. (2001) "The Demographic Imperative in Religious Change in the United States." The American Journal of Sociology 107(2): 468-500.

Iannaccone, L. R. (1990) "Religious Practice: A Human Capital Approach." Journal for the Scientific Study of Religion 29:297-314. 
Idler, E.L., Musick, M.A., Ellison, C.G., George, L.K., Krause, N, Ory, M.G., Pargament, K.I., Powell, L.H., Underwood, L.G., and Williams, D.R. "Measuring Multiple Dimensions of Religion and Spirituality for Health Research: Conceptual Background and Findings from the 1998 General Social Survey." Research on Aging 25:327-365.

Jones, E. F. and Westoff, F.C. (1979) "The End of 'Catholic' Fertility." Demography 16(2): 209_ 218.

Keister, L.A. (2003) "Religion and Wealth: The Role of Religious Affiliation and Participation in Early Adult Asset Accumulation." Social Forces 82: 173-205. (2005) Getting Rich: America's New Rich and How They Got that Way. Cambridge:

Cambridge University Press. (2009a) "Childhood Religious Denomination and Early Adult Asset Accumulation."

Forthcoming in C. Ellison and R. Hummer (eds.) Religion, Family Life, and Health in the United States, Rutgers University Press. (2009b) "Conservative Protestants and Wealth: How Religion Perpetuates Asset Poverty." Forthcoming in American Journal of Sociology.

Keysar, A. and Kosmin, B. (1995) "The Impact of Religious Identification on Differences in Educational Attainment Among American Women in 1990." Journal for the Scientific Study of Religion 34(1): 49-62.

Kosmin B.A. and Keysar, A. (2006) Religion in a Free Market. Ithaca, New York: Paramount Market Publishing, Inc.

Lehrer, E.L. (1995) "The Effects of Religion on the Labor Supply of Married Women." Social Science Research 24: 281-301.

--- (1996) "Religion as a Determinant of Fertility." Journal of Population Economics 9: 173-196. 
--- (1999) "Religion as a Determinant of Educational Attainment: An Economic Perspective." Social Science Research 28: 358-379.

--- (2003) "The Economics of Divorce." Pp. 55-74 in Shoshana Grossbard-Shechtman (ed.) Marriage and the Economy: Theory and Evidence from Industrialized Societies. Cambridge: Cambridge University Press.

--- (2004a) "Religion as a Determinant of Economic and Demographic Behavior in the United States." Population and Development Review 30(4): 707-726.

---- (2004b) "The Role of Religion in Union Formation: An Economic Perspective." Population Research and Policy Review 23: 161-185.

--- (2004c) "Religiosity as a Determinant of Educational Attainment: The Case of Conservative Protestant Women in the United States." Review of Economics of the Household 2(2): 203219.

---- (2005) "Religious Affiliation and Participation as Determinants of Women's Educational Attainment and Wages." Forthcoming in Christopher Ellison and Robert Hummer (eds.) Religion, Families and Health in the United States: New Directions in Population Based Research, Rutgers University Press.

--- (2009) Religion, Economics, and Demography: The Effects of Religion on Education, Work, and the Family. New York: Routledge Press.

Lehrer, E.L. and Chiswick, C.U. (1993) "Religion as a Determinant of Marital Stability." Demography 30(3): 385-404.

Lehrer, E.L., Lehrer, V.L., and Krauss, R. (2009) "Religion and Intimate Partner Violence in Chile: Macro- and Micro- Level Influences." Forthcoming in Social Science Research. Lemieux, T. (2008) "The Changing Nature of Wage Inequality." Journal of Population Economics 21:21-48. 
Lesthaege, R.J. and Neidert, L. (2006) "The Second Demographic Transition in the United States: Exception or Textbook Example?" Population and Development Review 32(4): 669698.

Levitt, H. M. and Ware, K. (2006) '"Anything with Two Heads is a Monster': Religious Leaders' Perspectives on Marital Equality and Domestic Violence." Violence Against Women, 12:11691190.

McLanahan, S. (2004) "Diverging Destinies: How Children are Faring Under the Second Demographic Transition." Demography 41(4): 607-627.

Mosher, W. D. and Hendershot, G. E. (1984) "Religion and Fertility: A Replication." Demography 21(2): 185-192.

Muller, C. and Ellison, C. G. (2001) 'Religious Involvement, Social Capital, and Adolescents' Academic Progress: Evidence from the National Education Longitudinal Study of 1988." Sociological Focus 34(2): 155-183.

Nason-Clark, N. 2004. "When Terror Strikes at Home: The Interface between Religion and Domestic Violence." Journal for the Scientific Study of Religion, 43(3): 303-310.

Pearce, L.D. and Axinn, W.G. (1998). "The Impact of Family Religious Life on the Quality of Mother-Child Relations." American Sociological Review 63(6): 810-828.

Potter, J.E., Amaral, E.F. and Woodberry, R.D. (2009) "The Growth of Protestantism in Brazil and its Impact on Income, 1970-2000." Presented at the meetings of the Association for the Study of Religion, Economics, and Culture, Detroit, Michigan.

Preston, S.H. and Sten Hartnett, C. (2009) "The Future of American Fertility." National Bureau of Economic Research, Working Paper 14498. 
Regnerus, M. D. (2000) "Shaping Schooling Success: Religious Socialization and Educational Outcomes in Metropolitan Public Schools." Journal for the Scientific Study of Religion 39:363-370.

- . - - (2007) Forbidden Fruit: Sex and Religion in the Lives of American Teenagers.

Oxford: Oxford University Press.

Roof, W.C. (1999) Spiritual Marketplace. Princeton: Princeton University Press.

Sander, W. (1992) "Catholicism and the Economics of Fertility," Population Studies, 46: 477-489.

Sherkat, D. E. (2000). "That They be Keepers of the Home: The Effect of Conservative Religion on Early and Late Transition into Housewifery." Review of Religious Research 41(3): 344-358.

- . - - - (2009) "Religion and Verbal Ability." Forthcoming in Social Science Research.

- . - - and Darnell, A. (1999) “The Effects of Parents' Fundamentalism on Children's

Educational Attainment: Examining Differences by Gender and Children's

Fundamentalism." Journal of the Scientific Study of Religion 38(1):23-35.

- - - - and Wilson, J. (1995). "Preferences, Constraints, and Choices in Religious

Markets: An Examination of Religious Switching and Apostasy." Social Forces 73(3):993-1026.

Smith, Christian. 2003. "Theorizing Religious Effects Among American Adolescents." Journal for the Scientific Study of Religion 42(1): 17-30

Stark, R. (1996) "Religion as Context: Hellfire and Delinquency One More Time." Sociology of Religion 56(2): 163-173.

- - - - and Finke, R. (2000) Acts of Faith: Explaining the Human Side of Religion.

Berkeley: University of California Press. 
Steensland, B., Park, J.Z., Regnerus, M.D., Robinson, L.D., Wilcox, W.B., and Woodberry, R.D. (2000) "The Measure of American Religion: Toward Improving the State of the Art." Social Forces 79(1): 1-28.

Stolzenberg, R.M., Blair-Loy, M. and Waite, L.J. (1995) "Religious Participation in Early Adulthood: Age and Family Life Cycle Effects on Church Membership." American Sociological Review 60:84-103.

Thornton, A., Axinn, W.G. and Hill, D.H. (1992) "Reciprocal Effects of Religiosity, Cohabitation, and Marriage." American Journal of Sociology 98(3): 628-651.

Trenholm, C., Devaney, B., Forston, K., Quay, L., Wheeler, J., and Clark, M. (2007) Impacts of Four Title V, Section 510 Abstinence Education Programs. Mathematica Policy Research, Inc. Available at: http://www.mathematica-mpr.com/publications/pdfs/impactabstinence.pdf Last accessed on June 29, 2009.

Uecker, J.E. and Stokes, C.E. (2009) "Early Marriage in the United States." Journal of Marriage and the Family 70(4):835-846.

Uecker, J.E., Regnerus, M.D. and Vaaler, M.L. (2007) "Losing My Religion: The Social Sources of Religious Decline in Early Adulthood." Social Forces 85(4): 1-26.

Vaaler, M.L., Ellison, C.G. and Powers, D.A. (2009) "Religious Influences on the Risk of Marital Dissolution." Forthcoming, Journal of Marriage and the Family.

Waite, L. and Lehrer, E.L. (2003) "The Benefits from Marriage and Religion in the United States: A Comparative Analysis." Population and Development Review 29(2): 255-275.

Westoff, C.F. and Jones, E.F. (1979) "The End of 'Catholic' Fertility." Demography 16: 209-218. 
Wilcox, W.B. and Wolfinger, N.H. (2006) "Then Comes Marriage? Religion, Race, and Marriage in Urban America." Social Science Research 36:569-589.

Williams, L. and Zimmer, B.G. (1990) "The Changing Influence of Religion on U.S. Fertility: Evidence from Rhode Island." Demography 27(3): 475-481.

Wolfinger, N.H. and Wilcox, W.B. (2008) "Happily Ever After? Religion, Marital Status, Gender and Relationship Quality in Urban Families." Social Forces 86(3):1311-1337.

Woodberry, R.D. and Smith, C.S. (1998) "Fundamentalism et al.: Conservative Protestants in America. Annual Review of Sociology 24: 25-56. 